\title{
Value Increase of Jetty Project Based on System Dynamics
}

\author{
Agung Prihantoro, Albert Eddy Husin* \\ Master of Civil Engineering, Universitas Mercu Buana, Jakarta Barat 11650, Indonesia
}

Received March 2, 2021; Revised April 28, 2021; Accepted May 16, 2021

\section{Cite This Paper in the following Citation Styles}

(a): [1] Agung Prihantoro, Albert Eddy Husin , "Value Increase of Jetty Project Based on System Dynamics," Civil Engineering and Architecture, Vol. 9, No. 3, pp. 892 - 898, 2021. DOI: 10.13189/cea.2021.090331.

(b): Agung Prihantoro, Albert Eddy Husin (2021). Value Increase of Jetty Project Based on System Dynamics. Civil Engineering and Architecture, 9(3), 892 - 898. DOI: 10.13189/cea.2021.090331.

Copyright $\odot 2021$ by authors, all rights reserved. Authors agree that this article remains permanently open access under the terms of the Creative Commons Attribution License 4.0 International License

\begin{abstract}
Waste or additional costs in infrastructure projects such as jetty projects are often caused by rework. Besides having an impact on costs, rework is also a very significant contributor to waste or add time which causes delays in the completion schedule of the project. A lot of research on rework has been carried out on both building and road construction projects, but there is no jetty construction project. This study aims to develop improvement scenarios to minimize the emergence of rework on pier infrastructure projects by modeling and simulating cost performance. The research variables were obtained based on the results of a literature study by asking for opinions from experts who are compatible in their scope. The initial model used the causal loop diagram form which was later developed into a Stock Flow Diagram, after which a repair simulation was carried out using the system dynamics method to determine the effect on cost performance. From the research results obtained 14 factors that affect the cost and time performance on the jetty project, the implementation of system dynamics can provide the optimum solution with the ability to reduce the percentage of the number of reworks by $24.12 \%$ for 12 months.
\end{abstract}

Keywords Jetty Project, Rework, System Dynamics, Cost-Efficiency

\section{Introduction}

Rework has a direct and indirect impact on project performance. This is an important factor that contributes to the costs and excess time of construction projects [1]. Waste of costs in transportation infrastructure projects, such as road projects, is often caused by rework [2], [3], [4]. The cost of rework on most construction projects is large, ranging from $5 \%$ to $20 \%$ of the contract value [5], [6]. Apart from having an impact on costs, rework is also a significant contributor to the time wastage and schedule delays of a project [7]. The average rework adds to the time required for project completion by $22 \%$ of the planned time [8]. An error during construction was ranked 5 th out of the total factors, and it was categorized under contractor related factors. If the contractor fails to execute the work per the contract or install unapproved material, it may lead to the demolition of the work, and then be reworked. This rework would invariably hinder the progress of work and subsequently result in a cost overrun [9]. Rework has also been indicated as a second cause for loss of worker productivity and is a frequent problem in both design and construction work [10].

To formulate the best solution in reducing the incidence of rework, it is necessary to simulate the model for the first time, according to [11] simulation can estimate system performance under certain conditions and provide the best design alternatives according to the desired specification. By looking at the variables causing the rework, which are always changing with time, such as rain whose characteristics can change every time, then the right type of simulation to use is a continuous simulation with a system dynamics approach.

Urban infrastructure encompasses the essential facilities, services, and social structures that ensure the productivity and well-being of cities and communities [12]. 10 sub-factors that have the most influence on the M-PERT scheduling of a toll road project which are the combination of project [13], Jetty is one of the infrastructures, implementation of the jetty construction 
work process with cost innovation using system dynamics can improve project performance in terms of cost in project management. The implementation of system dynamics in construction projects can reduce rework costs by $12.02 \%$ [14]. In the industrial world simulation using the system dynamics are the reliability of product handling, percentage of successful rework, and percentage of the deteriorated product. The simulation results show that the optimistic scenario has the smallest defect of $0 \%$ and is followed by a most likely scenario of $1 \%$ and a pessimistic scenario of $4 \%$ [15]. This research is expected to produce innovative studies as the best alternative recommendations in terms of project cost performance for service providers and service providers. By knowing the key factors in completing the jetty work, this research is expected to become a benchmarking or pilot for jetty projects.

\section{Methods}

This journal has the main variable to obtain results, namely the increase in cost performance on the jetty project, where the achievement of cost optimization is the dependent variable, while for the independent variables are a rework. The main variable aims to obtain optimal project performance results in terms of cost performance on jetty project work, these main variables can be identified in the main factor and divided into sub-factors which are expected to be interrelated variables. The results of the identification of the main variables which are supported by several sub-factors are then identified their effects on the integration of system dynamics methods and cost optimization in improving the performance of the pier project.

The arrangement of the instruments in this study was obtained from the identification of sub-variables based on previous journals, then the sub-variables were arranged into a research instrument in the form of a questionnaire in the form of question items, where the question items would be arranged by transforming the existing sub-variables. In the questionnaire distributed to selected respondents, the respondents will answer by choosing the answers provided.

After the variables have been distributed to experts, validation and reliability tests are carried out with the help of the Statistical Package for the Social Sciences (SPSS) program. With the validation and reliability testing done, it can be believed that each question item in this questionnaire can provide valid results, namely on the condition that $r$ count $>r$ table with a significance level of $5 \%$ and the Cronbach's Alpha value is greater than 0.60 .

After the variables are valid and realistic, the next stage is to carry out a second survey of respondents who are directly involved in the implementation of the jetty project. The process of data collection, data processing, using the Analytic Hierarchy Process (AHP) method with the help of Expert Choice software.
Table 1. Data of case study

\begin{tabular}{cc}
\hline Data & Explanation \\
\hline Location & Sorong, Papua Barat \\
Jetty & 3 segment \\
Trestle & 3 units \\
Causeway & 3 units \\
Dimension Jetty & $299.5 \mathrm{~m} \mathrm{x} 12 \mathrm{~m}$ \\
Dimension Trestle & $70 \mathrm{~m} \mathrm{x} 8 \mathrm{~m}$ \\
Dimension Causeway & $30 \mathrm{~m} \mathrm{x} 8 \mathrm{~m}$ \\
Owner & Indonesian Navy \\
Project Costs & IDR $168,586,103,000,-$ \\
Costs of Rework & IDR $8,065,549,000,-$ \\
\hline
\end{tabular}

From the results of the survey to respondents regarding the factors that influence cost performance on a jetty project with a system dynamics, the results of the Analytic Hierarchy Process (AHP) with the help of Expert Choice software and opinions from experts or advisors will get the order of the most influential factors (Key Success Factor) and the results of the case study analysis with the cost method using a system dynamics, it will be found whether the implementation of the system dynamics method on the jetty project can optimize the project in terms of costs.

\section{Results and Discussion}

\subsection{Most Influencing Factors}

The Analytic Hierarchy Process (AHP) processing stages with the help of Expert Choice software, after each main factor/criterion, sub-factor / criterion has been obtained then the next step is synthesis to get the overall weight of the existing criteria. Previously, the local priority had to be searched for the global value (global priority) first. The overall global weight value can be seen in table 2 . The data that have been calculated above show that the overall order of the factors that affect the cost and time performance on the pier project with the following results:

Table 2. The 14 most influential factors

\begin{tabular}{cc}
\hline Factor & Weight \\
\hline Design Change & $21.00 \%$ \\
Incompatible Working Methods & $12.70 \%$ \\
Lack of supervision & $11.70 \%$ \\
Delay in Work & $9.70 \%$ \\
Schedule that is too busy & $7.70 \%$ \\
Add Work & $7.40 \%$ \\
Lack of knowledge of PM and SM & $6.40 \%$ \\
Equipment Selection Error & $5.60 \%$ \\
Shortage of labor & $4.90 \%$ \\
Change in Specifications & $3.70 \%$ \\
Lack of Equipment & $3.00 \%$ \\
Delayed Material & $2.40 \%$ \\
Extreme weather & $2.20 \%$ \\
Slow Decision Making & $1.60 \%$ \\
\hline
\end{tabular}

\subsection{System Dynamics}

Systems Dynamics Methodology was first introduced 
by Jay Forrester from MIT (Massachusetts Institute of Technology) in the 1950s [16], [17]. In this scope of the study, the system is defined as a collection of elements that continuously interact over time to form a unified whole. System dynamics approach is adopted to simulate the scenarios, by using the data that are relevant to the real situation [18]. In this study, the stages in making a system dynamics model, the first step is to conceptualize the model. The second step is to create a causal loop diagram (CLD) which is obtained based on the results of questionnaire data collection on the factors that affect the cost performance of the pier project. The third step is to create a stock-flow diagram (SFD) based on the CLD that has been made previously. The fourth step is to determine the formulation of the input values of the variables in the created SFD. The fifth step is to validate the model against the SFD that has been made. The sixth step is to create scenarios and simulations based on the SFD that has been made by adding variables that can reduce rework on the jetty project.

\subsubsection{Causal Loop Diagram}

Causal loop diagrams must be finished before making a model so that the model maker has a first picture of the concept of the model to be made. Causal loop diagrams are useful for describing the relationship between variables involved in a system. The positive arrows indicate that the relationship is directly proportional, where the addition of value to the variable will cause an additional value to the variable it affects. Meanwhile, the arrow which is marked negative shows an inversely proportional relationship, where the addition of the value to this variable will cause a decrease in the value of the variable it affects.

From the CLD that has been made, it can be seen that each variable is interrelated, for example, the construction cost factor and the rework factor. The greater the construction cost, the more likely rework will occur, conversely, the smaller the construction cost, the less likely rework will occur. CLD describes the factors that affect the cost performance of the jetty project which are interrelated so that from the CLD results, SFD can be formed which will later become a model as a basis for scenario creation.

\subsubsection{Stock Flow Diagram}

The following table 3 is the value of each variable that affects the variable occurrence of rework on the jetty project obtained by using the weighting normalization technique obtained from the results of the expert choice software output using the analytical hierarchical process (AHP) method, which later these values entered into the Powersim program with the system dynamics method.

Before creating a scenario, first validation of the initial model that has been made is based on the causal loop diagram (CLD), validation testing is carried out utilizing the average comparison test and amplitude variation comparison test. It is said to be valid if the mean comparison value is $<5 \%$ and the amplitude variation comparison value is $<30 \%$.

Table 3. Weighted value on variables

\begin{tabular}{|c|c|}
\hline Factor & Explanation \\
\hline $\begin{array}{l}\text { Design } \\
\text { Change }\end{array}$ & $\begin{array}{l}\text { Design changes occurred during the initial } 3 \\
\text { months of project implementation, due to } \\
\text { differences in the results of sondir boring by the } \\
\text { Planning Consultant which resulted in changes in } \\
\text { pile length. }\end{array}$ \\
\hline $\begin{array}{l}\text { Incompatible } \\
\text { Working } \\
\text { Methods }\end{array}$ & $\begin{array}{l}\text { As a result of errors in equipment selection and } \\
\text { PM's lack of knowledge, the work method was } \\
\text { not following specifications. }\end{array}$ \\
\hline $\begin{array}{l}\text { Lack of } \\
\text { supervision }\end{array}$ & $\begin{array}{l}\text { During project implementation, the supervisory } \\
\text { team from the Supervision Consultant only } \\
\text { assigns } 1 \text { (one) personnel. }\end{array}$ \\
\hline $\begin{array}{c}\text { Lack of } \\
\text { knowledge of } \\
\text { PM and SM }\end{array}$ & $\begin{array}{l}\text { Lack of PM and SM's knowledge of the jetty } \\
\text { work that occurred during the construction } \\
\text { project. }\end{array}$ \\
\hline $\begin{array}{l}\text { Equipment } \\
\text { Selection } \\
\text { Error }\end{array}$ & $\begin{array}{l}\text { The main equipment is equipment for erection } \\
\text { work that is not following specifications, so the } \\
\text { Contractor brings back the main equipment which } \\
\text { takes up to } 3 \text { months. }\end{array}$ \\
\hline $\begin{array}{c}\text { Change in } \\
\text { Specifications }\end{array}$ & $\begin{array}{l}\text { Changes in specifications occur during the } \\
\text { implementation of the construction project }(12 \\
\text { months), which is caused by requests from the } \\
\text { owner or due to adjusting to field conditions. }\end{array}$ \\
\hline $\begin{array}{l}\text { Delayed } \\
\text { Material }\end{array}$ & $\begin{array}{l}\text { Material delays occurred for } 3 \text { months, due to } \\
\text { design changes due to differences in design } \\
\text { results with existing conditions. }\end{array}$ \\
\hline $\begin{array}{l}\text { Extreme } \\
\text { weather }\end{array}$ & $\begin{array}{l}\text { The occurrence of high tides so that disturbs } \\
\text { construction work, plus a high enough wave } \\
\text { during the construction work. }\end{array}$ \\
\hline
\end{tabular}

\subsubsection{Scenario}

The scenario model aims to improve system performance in overcoming existing problems, the type of scenario that will be carried out is an improvement scenario by adding several improvement scenarios. The following is a table of alternative scenarios for selecting rework cost savings if applied to similar projects. The following are some of the formulations of improvement scenarios used in this study:

Table 4. Scenario

\begin{tabular}{|c|c|}
\hline Scenario & Explanation \\
\hline $\begin{array}{l}\text { Pessimistic } \\
\text { scenario } \\
\text { (figure 1) }\end{array}$ & $\begin{array}{l}\text { Carry out project management training to PM and } \\
\text { SM }\end{array}$ \\
\hline $\begin{array}{l}\text { Mode } \\
\text { scen } \\
\text { (figu }\end{array}$ & $\begin{array}{l}\text { 1. Increase the number of supervisors, so that } \\
\text { construction is carried out according to the required } \\
\text { method. } \\
2 \text {. Add experts, so that problems in the field caused } \\
\text { by design changes can be minimized. }\end{array}$ \\
\hline $\begin{array}{l}\text { Optimistic } \\
\text { scenario } \\
\text { (figure 3) }\end{array}$ & $\begin{array}{l}\text { 1. Add to the survey the location of boring points, so } \\
\text { that the accuracy of boring results does not differ } \\
\text { from field conditions. } \\
\text { 2. Increase the number of supervisors, so that } \\
\text { construction is carried out according to the required } \\
\text { method. } \\
\text { 3. Add experts, so that problems in the field caused } \\
\text { by design changes can be minimized. } \\
\text { 4. Carry out project management training to PM and } \\
\text { SM. } \\
\text { 5. Carry out regular weekly meetings. }\end{array}$ \\
\hline
\end{tabular}




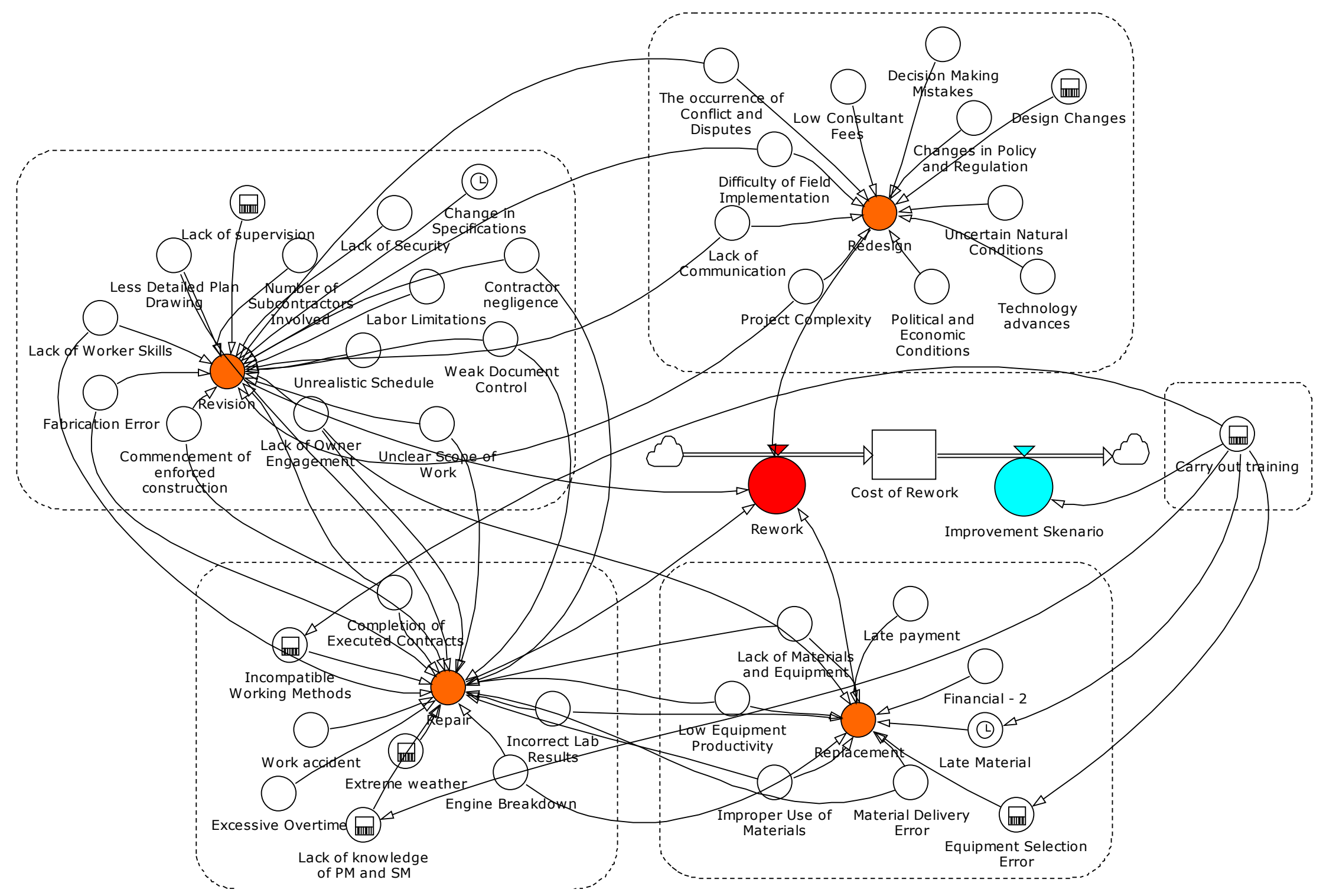

Figure 1. Stock flow diagram for pessimistic scenario 


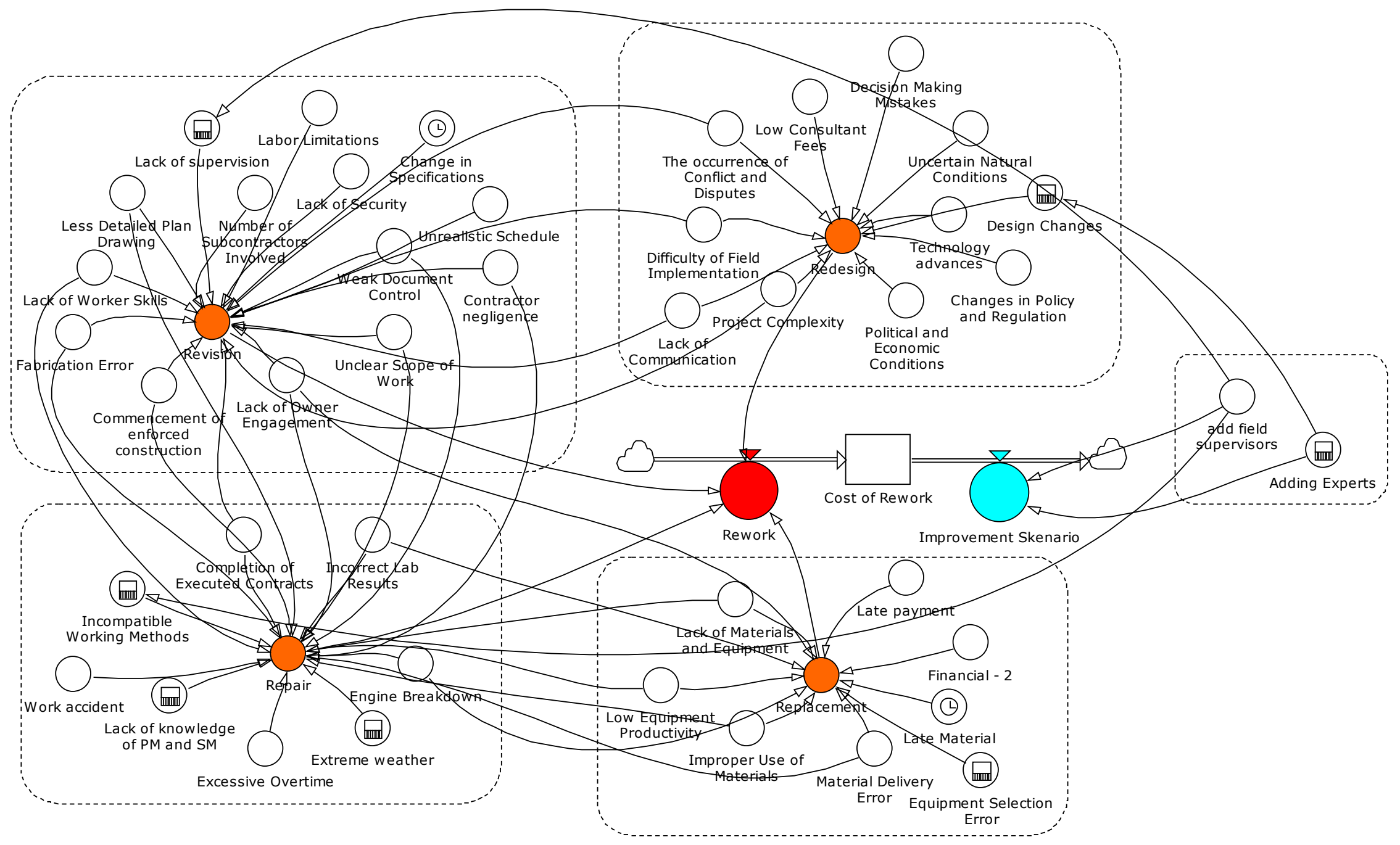

Figure 2. Stock flow diagram for the moderate scenario 


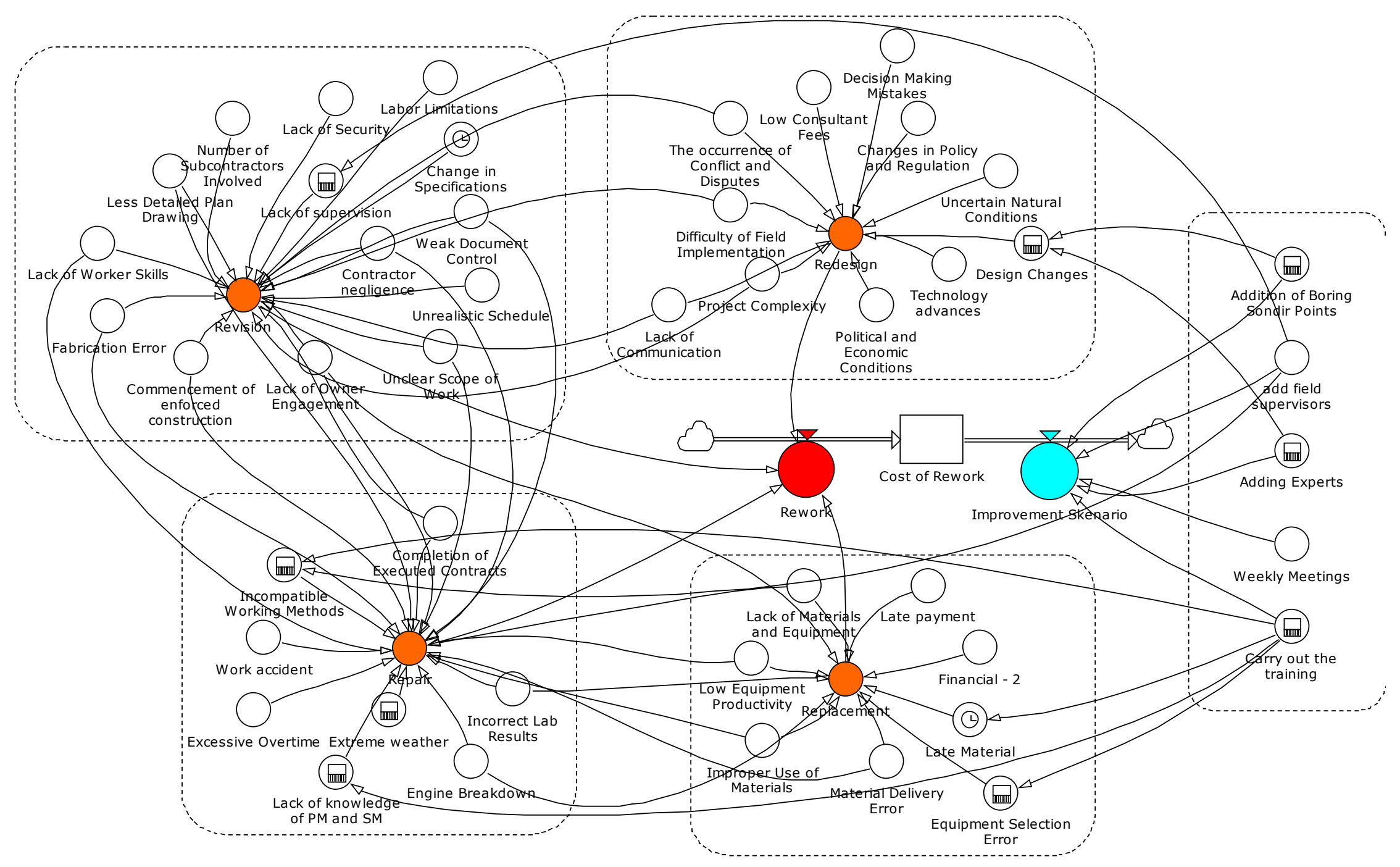

Figure 3. Stock flow diagram for the optimistic scenario 
From the scenario discussion above, if applied to a jetty construction project, the value of the savings can be calculated to minimize the rework on a similar pier construction project as in table 6 . The following is a table of alternative scenarios for selecting rework cost savings if applied to similar projects.

Table 6. Simulation results of rework improvements

\begin{tabular}{ccc}
\hline Scenario & Results & Rupiah (Rp.) \\
\hline pessimistic scenario & $1.73 \%$ & IDR 139,534,000 \\
moderate scenario & $12.95 \%$ & IDR $1,044,489,000$ \\
Optimistic scenario & $24.2 \%$ & IDR $1,945,411,000$ \\
\hline
\end{tabular}

\section{Conclusions}

Based on the results of research on minimizing rework on the pier project, 14 factors affect the cost performance of the jetty project, namely design changes, inappropriate work methods, lack of supervision, work delays, too-busy schedules, added work, lack of knowledge of PM and SM, selection errors equipment, labor shortages, specification changes, equipment shortages, late materials, extreme weather, slow decision making. From the system dynamics results obtained 3 selected scenarios can minimize rework on the jetty project, namely the pessimistic scenario reduces the rework by $1.73 \%$, the moderate scenario reduces the rework by $12.95 \%$ and the optimistic scenario reduces the rework by $24.12 \%$.

\section{Acknowledgments}

The author would like to thank the Indonesian Navy who was very helpful in providing project support data, and to my superiors, who provided comments and suggestions so that I could complete this research.

\section{REFERENCES}

[1] B. G. Hwang, S. R. Thomas, C. T. Haas, and C. H. Caldas, "Measuring the impact of rework on construction cost performance," J. Constr. Eng. Manag., 2009, doi: 10.1061/(ASCE)0733-9364(2009)135:3(187).

[2] A. E. Husin and I. Siregar, "Multi-Span Bridge work based on line of balance and critical path methods integration in light rapid train," ARPN J. Eng. Appl. Sci., vol. 14, no. 17, pp. 3001-3012, 2019.

[3] P. Barber, A. Graves, M. Hall, D. Sheath, and C. Tomkins, "Quality failure costs in civil engineering projects," Int. J. Qual. Reliab. Manag., 2000, doi: 10.1108/02656710010298 544.

[4] P. E. D. Love, C. P. Sing, X. Wang, Z. Irani, and D. W.
Thwala, "Overruns in transportation infrastructure projects," Struct. Infrastruct. Eng., 2014, doi:10.1080/15732479.2012 .715173 .

[5] J. L. Burati, J. J. Farrington, and W. B. Ledbetter, "Causes of Quality Deviations in Design and Construction," J. Constr. Eng. Manag., vol. 118, no. 1, pp. 34-49, 1992, doi: 10.1061/(asce)0733-9364(1992)118:1(34).

[6] Love and Sohal, "Capturing rework costs in projects," Manag. Audit. J., 2003, doi: 10.1108/02686900310474343.

[7] M. M. Kumaraswamy and D. W. M. Chan, "Contributors to construction delays," Constr. Manag. Econ., 1998, doi: 10.1080/014461998372556.

[8] Love, "Influence of project type and procurement method on rework costs in building construction projects," J. Constr. Eng. Manag., 2002, doi: 10.1061/(ASCE)0733-9364(2002) 128:1(18).

[9] A. M. Kamaruddeen, C. F. Sung, and W. Wahi, "A study on factors causing cost overrun of construction projects in Sarawak, Malaysia," Civil Engineering and Architecture, Vol. 8, No. 3, pp. 191-199, 2020, DOI: 10.13189/cea.2020.080301

[10] P. F. Kaming, P. O. Olomolaiye, G. D. Holt, and F. C. Harris, "Factors influencing construction time and cost overruns on high-rise projects in Indonesia," Constr. Manag. Econ., 1997, doi: 10.1080/014461997373132.

[11] S. Erma, "Pemodelan dan Simulasi," Pemodelan dan Simulasi, 2006.

[12] M. A. Berawi, "Managing sustainable infrastructure and urban development: Shaping a better future for Asean," Int. J. Technol., vol. 9, no. 7, pp. 1295-1298, 2018, doi: 10.14716/ijtech.v9i7.2731.

[13] A. E. Husin, B. D. Kussumardianadewi, J. M. Selatan, and K. J. Barat, "Research Article Time Performance Upgrade on Toll Road Construction Project By M-Pert," vol. 08, no. 01, pp. 3035-3042, 2019, doi: 10.13140/RG.2.2.19078.63048.

[14] A. E. Husin, M. A. Berawi, and T. Ilyas, "Forecasting Demand on Mega Infrastructure Projects: Increasing Financial Feasibility," no. October, 2015, doi: 10.14716/ijtech.v6i1.782.

[15] A. Suwandi, T. Y. Zagloel, and A. Hidayatno, "Risk Control Failure of Iron Pipes in Finished Goods Warehouses using Dynamic Systems," Int. J. Technol., vol. 12, no. 1, p. 15, 2021, doi: 10.14716/ijtech.v12i1.4068.

[16] A. Hidayatno, I. Rahman, and R. Muliadi, "Policy analysis of the Jakarta carbon mitigation plan using system dynamics to support decision making in urban development - options for policymakers," Int. J. Technol., 2015, doi: 10.14716/ijtech.v6i5.1926.

[17] E. Yuliawati, S. P. Hadiwardoyo, B. Susantono, and T. Tjahjono, "System dynamics model for airport characterization in huband- spoke networks," Int. J. Technol., 2015, doi: 10.14716/ijtech.v6i5.1039.

[18] I. Y. Mukti, Y. Prambudia, "System dynamics perspective of the apps-based transportation ecosystem," Civil Engineering and Architecture, Vol. 7, No. 3A, pp. 7-13, 2019, DOI: 10.13189/cea.2019.071302. 